\title{
PENERAPAN TEORI KONSTRUKTIVIS DALAM \\ PEMBELAJARAN \\ Fatimah Saguni
}

\begin{abstract}
Abstrak
Konstruktivisme merupakan landasan berpikir pendekatan kontekstual, yaitu bahwa pengetahuan dibangun bukanlah seperangkat fakta-fakta, konsep, atau kaidah yang siap untuk diingat. Siswa harus mengkonstruksi pengetahuan itu dan memberi makna melalui pengalaman nyata . Siswa perlu dibiasakan untuk memecahkan masalah, menemukan sesuatu yang berguna bagi dirinya, dan bergelut dengan ide-ide. Guru tidak akan mampu memberikan semua pengetahuan kepada siswa. Siswa harus mengkonstruksikan pengetahuan dibenak mereka sendiri. Pengetahuan tidak statis, tetapi berevolusi dan berubah secara konstan selama pelajar mengonstruksikan pengalaman-pengalaman baru yang memaksa mereka untuk mendasarkan diri dan memodifikasi pengetahuan sebelumnya.

Pembelajaran harus dikemas menjadi proses mengkonstruksi pengetahuan bukan menerima pengetahuan. Dalam proses pembelajaran, siswa membangun sendiri pengetahuan mereka melalui keterlibatan aktif dalam proses belajar dan mengajar. Siswa menjadi pusat kegiatan, bukan guru.

Berpikir kritis merupakan upaya yang dilakukan seseorang untuk memeriksa kebenaran dari suatu informasi menggunakan ketersediaan bukti, logika, dan kesadaran akan bias. Keterampilan berpikir kritis adalah proses kognitif siswa dalam menganalisis secara sistematis dan spesifik masalah yang dihadapi, membedakan masalah tersebut secara cermat dan teliti, serta mengidentifikasi dan mengkaji informasi guna merencanakan strategi pemecahan masalah.
\end{abstract}

Kata Kunci : berpikir kritis, konstruktivisme, Pembelajaran 


\section{Pendahuluan}

Revolusi konstruktivis mempunyai akar yang dalam pada sejarah pendidikan. Revolusi ini sangat banyak mengandalkan pada karya Piaget dan Vygotsky sebagai sumber yang keduanya menekankan bahwa perubahan kognisi hanya terjadi ketika konsepsi sebelumnya mengalami proses ketidakseimbangan (disequilibration) karena menekankan informasi baru. Piaget dan Vygotsky juga menekankan hakekat sosial pembelajaran, dan keduanya menyarankan penggunaan kelompok belajar dengan kemampuan campuran untuk meningkatkan perubahan konsep (Piaget dalam Robert E. Slavin). ${ }^{1}$ divisi psikologi pendidikan menerbitkan dokumen pada tahun 1992. Dokumen tersebut disebut Learner-Centered Psychology Principles: Guidelines for School Redesign and Reform. Dokumen yang direvisi pada tahun 1997 tersebut menghadirkan suatu pandangan bersama terhadap prinsip-prinsip belajar dan motivasi antara pada psikolog yang terkemuka di bidang pendidikan, yang terutama bekerja dalam tradisi konstruktivisme.

Salah satu perinsip terpenting psikologi pendidikan adalah bahwa guru tidak boleh hanya memberikan pengetahuan kepada siswa. Siswa harus membangun pengetahuan dalam pikirannya sendiri. Pendidikan adalah tiket ke masa depan. Hari esok dimiliki oleh orang-orang yang mempersiapkan dirinya sejak hari ini. Model konstruktivis metakognitif mengintegrasikan konsep schemata, konflik kognitif, asimilasi, akomodasi, dan equlibrasi dalam sintaks pembelajaran sebagai representasi karakter konstruktivis personal Piaget. Siswa yang belajar menggunakan model konstruktivis metakognitif akan dibimbing merencanakan, memantau, dan mengevaluasi ketercapain tujuan dan strategi pembelajaran sebagai representasi karakter strategi metakognitif. Pengembangan model pembelajaran konstuktivis-metakognitif secara parsial dinilai tidak berpengaruh maksimal terhadap pemberdayaan kemampuan berpikir dan kemandirian belajar siswa. ${ }^{2}$ David Ausubel terkenal dengan teori belajar yang dibawanya yaitu teori belajar bermakna (meaningful learning). Menurut Ausubel belajar bermakna terjadi jika suatu proses dikaitkannya informasi baru pada konsep-konsep yang relevan yang terdapat dalam struktur kognitif seseorang, selanjutnya bila tidak ada

\footnotetext{
${ }^{1}$ Rober E. Slavin, Psikologi Pendidikan Teori dan Praktek. (Jakarta: Boston, 2019) ,14.

${ }^{2}$ Baskoro Adi Prayitno dan Bowo Sugiharto. Komparasi Model Pembelajaran Konstruktivis Metakognitif Dan Konstruktivis Novick Terhadap Berpikir Kritis Ditinjau Dari Kemampuan Akademik. INFERENSI, Jurnal Penelitian Sosial Keagamaan. Vol. 11, No.1, Juni 2017, 26
} 
usaha yang dilakukan untuk mengasimilasikan pengertian baru pada konsep-konsep yang relevan yang sudah ada dalam struktur kognitif, maka akan terjadi belajar hafalan. Ia juga menyebutkan bahwa proses belajar tersebut terdiri dari dua proses yaitu proses penerimaan dan dan proses penemuan (Dahar, Ratna Wilis). ${ }^{3}$ Dengan demikian bahwa keaktifan siswa menemukan konsep baik sendiri maupun diskusi kelompok membuat proses belajar menjadi bermakna.

\section{Pembahasan}

Konstruktivisme adalah sebuah teori yang memberikan kebebasan terhadap manusia yang ingin belajar atau mencari kebutuhannya dengan kemampuan untuk menemukan keinginan atau kebutuhannya tersebut dengan bantuan fasilitas orang lain. Manusia untuk belajar menemukan sendiri kompetensi, pengetahuan atau teknologi dan hal yang diperlukan guna mengembangkan dirinya (Thobroni). ${ }^{4}$ Suatu hal yang perlu diingat, tidak mungkin untuk menciptakan sebuah pembelajaran konstruktivis yang bersifat "generik", berlaku untuk semua situasi. Menurut sifatnya, konstruktivisme Konstruktivisme (construktism) merupakan landasan berfikir pendekatan kontekstual, pengetahuan dibangun sedikit demi sedikit, hasilnya diperluas melalui konteks yang terbatas (sempit) dan tidak dengan tiba-tiba (Sagala). ${ }^{5}$

Bakti Gunawan menyatakan bahwa perkembangan manusia adalah sesuatu yang tidak terpisahkan dari kegiatan-kegiatan sosial dan budaya, yang merupakan suatu proses-proses perkembangan mental seperti ingatan, perhatian, dan penalaran yang melibatkan pembelajaran dengan menggunakan temuan-temuan masyarakat. Perkembangan kognitif sosial siswa merupakan hal penting untuk diperhatikan, karena merupakan kawasan yang membutuhkan pemrosesan yang sangat serius dalam membentuk karakter dalam rangka meningkatkan potensi ingatan dan penalaran yang lebih baik. Untuk memaksimalkan perkembangan, seharusnya anak bekerja dengan teman yang lebih terampil (lebih dewasa) yang dapat

\footnotetext{
4 Thobroni. Belajar dan Pembelajaran. (Yogyakarta: Ar-Ruzz Media2015), 91

5 Sagala, Syaiful. Konsep dan Makna Pembelajaran Untuk Membantu Memecahkan Problematika Belajar dan Mengajar. (Bandung: Alfabeta, 2007), 88
}

${ }^{3}$ Dahar, Ratna Wilis, Teori Belajar,( Jakarta : Erlangga Press,1989), 25 
memimpin secara sistematis dalam memecahkan masalah yang lebih kompleks. ${ }^{6}$

Proses Belajar Konstruktivistik

Proses belajar konstuktivistik berupa "Constructing and restructuring of knowledge and skills within the individual in a complex network of increasing conceptual consistently". Membangun dan merestrukturisasi pengetahuan dan keterampilan individu dalam lingkungan sosial dalam upaya peningkatan konseptual secara konsisten. Oleh sebab itu pengelolaan pembelajaran harus diutamakan pada pengelolaan peserta didik dalam memproses gagasannya bukan semata-mata olahan peserta didik dan lingkungan belajarnya bahkan prestasi belajarnya yang dikaitkan dengan sistem penghargaan dari luar seperti nilai ijazah dan sebagainya. Penerapan teori belajar Konstruktivisme sering digunaka pada model pembelajaran pemecahan masalah (problem solving seperti pembelajaran menemukan (discovery learning) dan pembelajaran berbasis masalah (problem-based learning). ${ }^{7}$

Untuk memperbaiki pendidikan harus diketahui bagaimana manusia belajar dan bagaimana cara pembelajarannya. Pengetahuan seseorang merupakan konstruksi (bentukan) dari dirinya. Pengetahuan bukanlah kumpulan fakta dari suatu kenyataan yang sedang dipelajari melainkan sebagai konstruksi kognitif seseorang terhadap objek, pengalaman maupun lingkungannya. Pengetahuan bukanlah sesuatu yang sudah ada dan tersedia, sementara orang lain tinggal menerimanya. Pengetahuan adalah sebagai suatu pembentukan yang terus menerus oleh seseorang yang setiap saat mengalami reorganisasi karena adanya pemahaman-pemahaman baru. Bila pendidik bermaksud menstranfer konsep, ide dan pengetahuan tentang sesuatu kepada siswa, pentransferan itu akan diinterpretasikan dan dikonstruksi oleh mahasiswa melalui pemahaman dan pengetahuan mereka sendiri. ${ }^{8}$

6 Bakti Gunawan. Penerapan Teori Belajar Vygotsky Dalam Interaksi Belajar Mengajar https://www.kompasiana.com/baktigunawan/ 550d985b8133115d22b1e4d8/penerapan-teori-belajar-vygotsky-dalaminteraksi-belajar-mengajar diakses tanggal 6 Januari 2020.

${ }^{7}$ Badaruzzaman. Proses Belajar Menurut Teori belajar Konstruktivisme, 2018

https://www.dasarguru.com/proses-belajar-menurut-teori-belajar-

konstruktivisme/

8 Sumarsih. Implementasi Teori Pembelajaran Konstruktivistik Dalam Pembelajaran Mata Kuliah Dasar-Dasar Bisnis. Jurnal Pendidikan Akuntansi Indonesia Vol. VIII. No. 1 - Tahun 2009 hal 54 - 62 
Peranan Dosen

Dalam pembelajaran konstruktivistik, dosen atau pendidik berperan membantu agar proses pengkonstruksian pengetahuan oleh mahasiswa berjalan lancar. Pendidik tidak mentransferkan pengetahuan yang dimilikinya, melainkan membantu mahasiswa untuk membentuk pengetahuannya sendiri. Dosen dituntut untuk lebih memahami jalan fikiran atau cara pandang mahasiswa dalam belajar. Dosen tidak mengklaim bahwa satu-satunya cara yang tepat adalah yang sama dan

sesuai dengan kemampuannya. Menurut prinsip pembelajaran konstruktivistik, seorang pengajar atau dosen berperan sebagai mediator dan fasilitator yang membantu agar proses belajar mahasiswa berjalan dengan baik yaitu;

a) Menyediakan pengalaman belajar yang memungkinkan mahasiswa bertanggungjawab, memberi kuliah atau ceramah bukanlah tugas utama seorang dosen

b) Menyediakan atau memberikan kegiatan-kegiatan yang merangsang keingintahuan mahasiswa dan membantu mereka untuk mengekspresikan gagasannya dan mengkomunikasikan ide ilmiah mereka, menyediakan sarana secara produktif menyediakan kesempatan dan pengalaman yang paling mendukung proses belajar mahasiswa.

Salah satu prinsip utama dalam psikologi pendidikan adalah guru tidak bisa hanya memberikan pengetahuan kepada siswa. Siswa harus membangun pengetahuan dalam pikiran mereka sendiri. Guruguru dapat menfasilitasi proses ini dengan pengajaran dengan cara membuat informasi bermakna dan berkaitan dengan siswa; dengan memberikan kesempatan kepada siswa untuk menemukan dan menerapkan ide-ide mereka sendiri. Guru mengajarkan kepada siswa untuk bangkit dan secara sadar menggunakan strategi mereka sendiri untuk belajar. Gambarannya seperti guru dapat memberikan tangga yang membimbing siswa menuju pemahaman yang lebih tinggi, dan siswa dengan sendirinya harus bisa mendaki tangga tersebut (Slavin). Dalam model SCL ini, guru lebih tepatnya disebut sebagai fasilitator pembelajaran, dapat juga disebut sebagai mediator. ${ }^{9}$

Peranan mahasiswa

Menurut pandangan konstruktivistik belajar merupakan suatu proses pembentukan pengetahuan. Pembentukan ini harus dilakukan

9 Slavin, Robert E. Educational Psychology: Theory and Practice. $8^{\text {th }}$ Edition. (Boston: Pearson Education, Inc. 2006), 230 
individu yang belajar. Ia harus aktif melakukan kegiatan, aktif berfikir, menyusun konsep dan memberi makna tentang hal-hal yang dipelajari. Dosen memang dapat dan harus mengambil prakarsa untuk menata lingkungan yang memberi peluang optimal bagi terjadinya belajar. Namun yang akhirnya paling menentukan terwujudnya gejala belajar adalah niat belajar mahasiswa itu sendiri. Dengan istilah lain dapat dikatakan bahwa pada hakikatnya kendali belajar sepenuhnya ada pada mahasiswa. Paradigma konstruktivistik memandang mahasiswa sebagai pribadi yang memiliki kemampuan awal sebelum mempelajari sesuatu pengetahuan yang baru. Bagi kontruktivistik, kegiatan belajar adalah kegiatan aktif mahasiswa untuk menemukan sesuatu dan membangun sendiri pengetahuannya, bukan merupakan proses mekanik untuk mengumpulkan fakta. Mahasiswalah yang bertanggungjawab atas hasil belajarnya. Mahasiswa yang membuat penalaran atas apa yang dipelajari dengan cara mencari makna, membandingkannya dengan apa yang telah diketahui serta menyelesaikan ketidaksamaan antara apa yang telah diketahui dengan apa yang diperlukan dalam pengalaman baru. Setiap mahasiswa mempunyai cara yang cocok untuk mengkontruksikan pengetahuannya yang kadang-kadang sangat berbeda dengan temanteman yang lain. Dalam hal ini sangat penting bahwa mahasiswa dimungkinkan untuk mencoba bermacam-macam cara belajar yang cocok dan juga penting bahwa dosen menciptakan bermacam-macam situasi dan metode yang membantu mahasiswa. Satu pembelajaran saja tidak akan banyak membantu mahasiswa.

Deskripsi partisipasi mahasiswa berdasarkan indikator partisipasi disajikan sebagai berikut.

1. Berbuat sesuatu untuk memahami materi pelajaran dengan

penuh keyakinan

Berdasarkan hasil pengamatan, sebagian besar mahasiswa telah berpartisipasi aktif dalam kegiatan pembelajaran dengan cara memperhatikan penjelasan dosen, mencatat, mengajukan pertanyaan kepada dosen mengenai halhal yang masih membingungkan dan menuliskan jawaban dari soal yang diberikan di papan. Namun terdapat beberapa mahasiswa yang berpartisipasi secara pasif yakni hanya mendengarkan tanpa membuat catatan. Selain itu, pada pertemuan pertama, terdapat seorang mahasiswa yang terlihat kurang fokus terhadap kegiatan pembelajaran dan tidak mencatat penjelasan dosen model. Selain itu, mahasiswa yang mengajukan pertanyaan atau ide didominasi oleh 
beberapa mahasiswa, sehingga dosen perlu menunjuk mahasiswa tertentu yang kurang aktif.

2. Mempelajari, mengalami, dan menemukan sendiri pengetahuan mereka.

Pada setiap pertemuan, konsep pertama yang akan diajarkan dibangun oleh mahasiswa. Dosen memberikan pertanyaan bimbingan untuk membimbing mahasiswa dalam mengonstruk konsep yang benar.

Cornelius-White menyatakan bahwa Penekanan pada siswa sebagai pebelajar aktif, strategi konstruktivis sering disebut pengajaran yang berpusat pada siswa (student-centered instruction) ${ }^{10}$. Hal ini di pertegas oleh Noddings bahwa di ruang kelas yang berpusat pada siswa, guru menjadi pemandu disamping dan bukan orang bijaksana di atas panggung, dengan membantu siswa menemukan pengertian mereka sendiri dan bukan mengajari dan mengendalikan semua kegiatan di ruang kelas. ${ }^{11}$

\section{Sarana Belajar}

Konstruktivistik menekankan bahwa peranan utama dalam kegiatan belajar adalah aktivitas mahasiswa dalam mengkonstruksi pengetahuannya sendiri. Segala sesuatu seperti bahan, peralatan, lingkungan dan fasilitas lainnya disediakan untuk membantu pembentukan tersebut. Mahasiswa diberi kebebasan untuk mengungkapkan pendapat dan pemikirannya sendiri tentang sesuatu yang dihadapi. Dengan cara demikian mahasiswa akan terbiasa dan terlatih untuk berfikir kritis, kreatif, dan mampu mempertanggungjawabkan pemikirannya secara rasional.

\section{Berpikir Kritis}

Berpikir kritis dapat diartikan sebagai upaya seseorang untuk memeriksa kebenaran dari suatu informasi menggunakan ketersediaan bukti, logika, dan kesadaran akan bias (Halpern, 1998; Larsson, 2017). Mengingat kondisi sosial yang semakin kompleks dan kemajuan teknologi informasi, mendorong derasnya pertukaran informasi yang belum terverifikasi. ${ }^{12}$ Sebelum seseorang mampu berpikir kritis sesuai proses diatas, ia perlu memiliki kemampuan dasar berpikir.

10 Cornelius-White, J. (2007) Learner-centered teacher-student relationships are effective: A meta-analysis. Review of Educational Research, 77(1), 113-143

11 Noddings, N. (2008). All our students thinking. Educational Leadership, 65 (5), 8-13.

${ }_{12}$ Ahmad Sulaiman dan Nandy Agustin Syakarofath. Berpikir Kritis: Mendorong Introduksi dan Reformulasi Konsep dalam Psikologi Islam. Buletin Psikologi . 2018, Vol. 26, No. 2, 86 - 96: 86 
Kemampuan berpikir berkaitan dengan aspek kognitif/mentalintelektual dalam perkembangan manusia. Aspek ini sudah berkembang sejak struktur otak terbentuk di masa anak masih di dalam kandungan, khususnya pada bulan-bulan terakhir, berlanjut hingga tahun-tahun awal kehidupan. Pada usia 2 tahun volume otak anak sudah bertambah tiga kali lipat menjadi $75 \%$ otak orang dewasa. Dengan kata lain, masa ini adalah periode saat kemampuan kognitif berkembang sangat pesat. Mereka belajar memahami dunia yang baru dikenalnya, belajar berbicara, belajar mengekspresikan perasaannya, dan sebagainya. Mereka berpikir, "Ini ibu saya bukan ya? Saya lapar, mana makanan saya ya, sepertinya saya harus menangis lebih keras agar mereka tahu saya lapar..." Ini semua kegiatan berpikir. Sudah tentu kemampuan berpikir kritis tidak dapat berkembang semasa janin di kandungan karena berpikir kritis merupakan kemampuan berpikir yang luhur/tinggi. Namun, kemampuan mental luhur ini tidak dapat dicapai tanpa proses latihan/stimulasi, dan dasarnya adalah kemampuan berpikir secara umum. ${ }^{13}$

Cukwuyenum (2013) menjelaskan berpikir kritis meliputi usaha seseorang dalam mengumpulkan, menafsirkan, menganalisis dan mengevaluasi informasi untuk sampai pada simpulan yang dapat diandalkan dan valid. ${ }^{14}$ Sementara itu Shapiro (dalam Mohammad Faizal Amir) mengungkapkan berpikir kritis adalah suatu aktivitas mental yang berkaitan dengan penggunaan nalar yang menggunakan proses mental seperti memperhatikan, mengkategorikan, menyeleksi, dan memutuskan pemecahan suatu masalah. ${ }^{15}$ Keterampilan berpikir kritis adalah proses kognitif siswa dalam menganalisis secara sistematis dan spesifik masalah yang dihadapi, membedakan masalah tersebut secara cermat dan teliti, serta mengidentifikasi dan mengkaji informasi guna merencanakan strategi pemecahan masalah. ${ }^{16}$ Senada

${ }^{13}$ Tim Dosen Fakultas Psikologi Unika Atma Jaya. Mempersiapkan Generasi Milenial Ala Psikolog: Kiat-kiat pendidikan anak bagi orang tua dan guru. (Jakarta : PT Kompas Media Nusantara, 2018), 70

14 Chukwuyenum, A.N. (2013). Impact of Critical Thinking of Performance in Mathematics Among Senior Secondary School Student in Lagos State. Journal of Research \& Metode in Education. Vol. 3 Issue 5, pp. $18-25$

${ }^{15}$ Mohammad Faizal Amir. Proses Berpikir Kritis Siswa Sekolah Dasar Dalam Memecahkan Masalah Berbentuk Soal Cerita Matematika Berdasarkan Gaya Belajar. (Jurnal Math Educator Nusantara Volume 01 Nomor 02, Nopember 2015), 162

${ }^{16}$ Mira Azizah1, Joko Sulianto , Nyai Cintang. Analisis Keterampilan Berpikir Kritis 
dengan pendapat tersebut diperkuat oleh Stobaugh. yang menjelaskankan bahwa berpikir kritis adalah berpikir yang reflektif secara mendalam dalam pengambilan keputusan dan pemecahan masalah untuk menganalisis situasi, mengevaluasi argumen, dan menarik kesimpulan yang tepat. ${ }^{17}$ Hal yang sama juga dijelaskan oleh Krathwohl (lewy, 2009:16), bahwa berpikir kritis termasuk keterampilan berpikir tingkat tinggi yang meliputi proses menganalisis (C4) dan mengevaluasi (C5). Proses kognitif menganalisis meliputi: menganalis informasi termasuk membagi-bagi atau menstrukturkan informasi untuk mengenali pola atau hubungannya, mengidentifikasi/ merumuskan pertanyaan, dan mengenali serta membedakan faktor penyebab dan akibat dari sebuah permasalahan. Sedangkan proses kognitif mengevaluasi meliputi: memberikan penilaian terhadap solusi, gagasan, dan metodologi dengan menggunakan kriteria yang cocok atau standar yang ada untuk memastikan nilai efektivitas atau manfaatnya, membuat hipotesis, mengkritik, dan melakukan pengujian, serta menerima atau menolak suatu pernyataan berdasarkan kriteria yang telah ditetapkan. Dengan demikian berpikir kritis termasuk dalam keterampilan berpikir tingkat tinggi.

Konstruktivisme psikologis terfokus pada bagaimana individu membangun elemen-elemen tertentu dari aparatus kognitif atau emosionalnya (Phillips, D.C. dalam Dadang Supardan). Para konstruktivis ini tertarik dengan pengetahuan, keyakinan, konsepkonsep diri, atau identitas individual, sehinnga mereka kadang-kadang disebut konstruktivis individual, atau konstruktivis psikologi-kognitif, atau konstruktivis endogenous; mereka semuanya memfokuskan pada kehidupan psikologis dalam diri orang. ${ }^{18}$

Teori Pembelajaran yang didasarkan pada gagasan ini disebut teori pembelajaran konstruktivis (constructivis theories of learning). Inti teori konstruktivis ialah gagasan bahwa masing-masing pelajar harus menemukan dan mengubah informasi yang rumit jika mereka ingin menjadikannya milik sendiri (Anderson, Greeno, rader, Simon

Siswa Sekolah Dasar Pada Pembelajaran Matematika Kurikulum 2013. (Jurnal Penelitian Pendidikan Vol. 35 Nomor 1 Tahun 2018), 62

17 Stobaugh, R. Assesing Critical Thinking in Middle and High Schools: Meeting the Common Core. New York: Routledge, 2013), 2

${ }^{18}$ Dadang Supardan. Teori Dan Praktik Pendekatan Konstruktivisme Dalam Pembelajaran

Edunomic: Volume 4 No. 1 Tahun 2016. 
\&Fosnot). ${ }^{19}$ Pandangan ini mempunyai implikasi yang sangat besar bagi pengajaran, karena itu menyarankan peran siswa yang sangat besar bagi pengajaran. Peran siswa yang jauh lebih aktif dalam pembelajaran mereka sendiri dari pada yang biasanya ditemukan di banyak ruang kelas.

Model Konstruktivisme Gagnon \& Collay dalam Dadang Supardan yang terdiri atas enam tahapan, yakni; (a) Situasi: gambarkan situasi tertentu yang berhubungan dengan tema/topik pembhs; (b) Pengelompokan: buat kelompok bisa berdasarkan no urut maupun campuran tingkat kecerdasannya; (c) Jembatan; memberikan suatu masalah sederhana/permainan/ teka-teki untuk dipecahkan; (d) Pertanyaan; buat pertanyan pembuka maupun kegiatan inti agar siswa tetap termotivasi untuk belajar lebih jauh; (e) Mendemonstrasikan: memajangkan/memamerkan/menyajikan hasil kerja siswa di kelas; (f) Refleksi: merenungkan, menindak-lanjuti laporan kelompok yang dipresentasikan. ${ }^{20}$

Tahapan-tahapan dalam pembelajaran dengan pendekatan konstruktivisme, yaitu sebagai berikut:

a. Tahap pertama, peserta didik didorong agar mengemukakan pengetahuan awalnya tentang konsep yang akan dibahas. Bila perlu, guru memancing dengan pertanyaan problematik tentang fenomena yang sering dijumpai sehari-hari oleh peserta didik dan mengaitkannya dengan konsep yang akan dibahas.

Selanjutnya, peserta didik diberi kesempatan untuk mengkomunikasikan dan mengilustrasikan pemhamannya tentang konsep tersebut.

b. Tahap kedua, peserta didik diberi kesempatan untuk menyelidiki dan menemukan konsep melalui pengumpulan, pengorganisasian, dan penginterprestasian data dalam suatu kegiatan yang telah dirancang oleh guru. Secara keseluruhan dalam hidup ini akan terpenuhi rasa keingintahuan peserta didik tentang fenomena dalam lingkungannya.

c. Tahap ketiga, peserta didik melakukan penjelasan dan solusi yang didasarkan pada hasil observasi peserta didik, ditambah dengan penguatan guru. Selanjutnya peserta didik membangun pemahaman baru tentang konsep yang sedang dipelajari.

${ }^{19}$ Anderson, J. R., Greeno, J.G., Reder, L.M., \& Simon, H. (2000). Perspectives on learning, thinking, and activity. Educational Researcher, 29(4), 11-13

20 Dadang Supardan. Teori Dan Praktik Pendekatan Konstruktivisme, 2016, 3 
d. Tahap keempat, guru berusaha menciptakan iklim pembelajaran yang memungkinkan peserta didik dapat mengaplikasikan pemahaman konseptualnya, baik melalui kegiatan maupun pemunculan masalahmasalah yang berkatian dengan isu-isu dalam lingkungan peserta didik tersebut (Yager dalam Lapono, $\mathrm{dkk},)^{21}$

\section{Penerapan pendekatan konstruktivisme}

Penerapan pendekatan konstruktivisme di dalam kelas adalah sebagai berikut: a) Kembangkan pemikiran bahwa anak akan belajar lebih bermakna dengan cara bekerja sendiri, menemukan sendiri, dan mengkonstruksikan sendiri pengalaman dan keterampilan barunya b) Laksanakan sejauh mungkin kegiatan inquiri untuk semua topik c) Kembangkan sifat ingin tahu siswa dengan bertanya. d) Citpakan "Masyarakat Belajar" (belajar dalam kelompok -kelompok) (Abimanyu Soli, dkk.). ${ }^{22}$ Berlandaskan teori belajar sosial, kognitif, dan konstruktif untuk memperoleh hasil belajar berupa keterampilan akademik, inquiry dan sosial. Jadi ciri model ini adalah kerja kelompok yang didasarkan pada penyelidikan dan penemuan melalui struktur tugas, ada ganjaran kelompok, dan penilaian yang otentik secara fleksibel, demonstrasi, dan berpusat pada siswa.

Aplikasi Teori Konstruktivistikd alam Pembelajaran :

a) Membebaskan siswa dari belenggu kurikulum yang berisi faktafakta lepas yang sudah ditetapkan, dan memberikan kesempatan kepada siswa untuk mengmbangkan ide-idenya secara lebih bebas.

b) Menempatkan siswa sebagai kekuatan timbulnya interes, untuk membuat hubungan ide-ide atau gagasan-gagasan, kemudian memformulasikan kembali ide-ide tersebut, serta membuat kesimpulan-kesimpulan.

c) Guru bersama-sama siswa mengkaji pesan-pesan penting bahwa dunia adalah kompleks, dimana terjadi bermacam-macam pandangan tentang kebenaran yang datangnya dari berbagai interpretasi.

d) Guru mengakui bahwa proses belajar serta penilaianya merupakan suatu usaha yang kompleks, sukar dipahami, tidak teratur, dan tidak mudah dikelola.

Banyak sekolah mengelola perbedaan siswa di bidang kemampuan dan pencapaian akademis melalui pengelompokkan

${ }^{21}$ Lapono, N, dkk. Belajar Dan Pembelajaran SD. Jakarta: Dirjen Pendidikan Tinggi Depdiknas, 2008), 328

${ }^{22}$ Abimanyu, Soli. dkk. Strategi Pembelajaran. (Jakarta: Direktorat Jendral Pendidikan Tinggi Departemen Pendidikan Nasional, 2008), 22 
kemampuan antar kelas, penjaluran, atau pengelompokkan kembali ke dalam kelas terpisah untuk mata pelajaran tertentu selama sebagian dari hari sekolah. Namun, riset memperlihatkan pengelompokkan dalam-kelas lebih efektif, khususnya untuk pelajaran membaca dan matematika, dan jelas lebih disukai daripada pengelompokkan yang memisahkan atau memberi stigma bagi siswa yang berpencapaian rendah. Penghapusan jalur merekomendasikan agar siswa ditempatkan ke kelompok dengan kemampuan campuran. Siswa diharuskan mencapai standar yang tinggi dan diberi bantuan untuk mencapai tujuan tersebut. Sekolah dasar tanpa kelas menggabungkan anak-anak dari usia yang berbeda di ruang kelas yang sama. Siswa secara fleksibel dikelompokkan sesuai dengan kebutuhan dan tingkat kinerjanya.

Keikutsertaan siswa dalam proses pembelajaran akan menumbuhkan keinginan untuk belajar secara mandiri. Aktivitas belajar dapat diartikan sebagai pengembangan diri melalui pengalaman bertumpu pada kemampuan diri di bawah bimbingan tenaga pengajar. Aktivitas belajar merupakan faktor yang sangat menentukan keberhasilan proses belajar mengajar siswa, karena pada prinsipnya belajar adalah berbuat, "learning by doing" (Sardiman). ${ }^{23}$

\section{Kesimpulan}

Konstruktivistik menekankan peranan utama dalam kegiatan belajar adalah aktivitas mahasiswa dalam mengkonstruksi pengetahuannya sendiri. Segala sesuatu seperti bahan, peralatan, lingkungan dan fasilitas lainnya disediakan untuk membantu pembentukan tersebut. Mahasiswa diberi kebebasan untuk mengungkapkan pendapat dan pemikirannya sendiri tentang sesuatu yang dihadapi. Dengan cara demikian mahasiswa akan terbiasa dan terlatih untuk berfikir kritis, kreatif, dan mampu mempertanggungjawabkan pemikirannya secara rasional.

Berbagai model dapat diterapkan dalam pembelajaran bagi mahasiswa. Model tersebut dapat divariasikan dan diterapkan secara bergantian sesuai dengan kebutuhan siswa. Model yang digunakan tentunya juga mempertimbangkan efektivitas dan efisiensi. Model yang diterapkan disesuaikan dengan waktu pembelajaran dan tujuan yang akan dicapai. Dosen selaku fasilitator seyogyanya mampu memilih model yang paling tepat untuk digunakan.

23 A.M, Sardiman. Interaksi dan Motivasi Belajar Mengajar. (Jakarta : Raja Grafindo Persada, 2007), 15 
Keterampilan berpikir kritis merupakan proses kognitif siswa dalam menganalisis secara sistematis dan spesifik masalah yang dihadapi, membedakan masalah tersebut secara cermat dan teliti, serta mengidentifikasi dan mengkaji informasi guna merencanakan strategi pemecahan masalah. berpikir kritis meliputi usaha seseorang dalam mengumpulkan, menafsirkan, menganalisis dan mengevaluasi informasi untuk sampai pada simpulan yang dapat diandalkan dan valid. Suatu aktivitas mental yang berkaitan dengan penggunaan nalar yang menggunakan proses mental seperti memperhatikan, mengkategorikan, menyeleksi, dalam pengambilan keputusan dan pemecahan masalah untuk menganalisis situasi, mengevaluasi argumen, dan menarik kesimpulan yang tepat.

\section{DAFTAR PUSTAKA}

Abimanyu, Soli. dkk. Strategi Pembelajaran. Jakarta: Direktorat Jendral Pendidikan Tinggi Departemen Pendidikan Nasional, 2008

Anderson, J. R., Greeno, J.G., Reder, L.M., \& Simon, H. Perspectives on learning, thinking, and activity. Educational Researcher, 2000. 29(4), 11-13.

Ahmad Sulaiman dan Nandy Agustin Syakarofath. Berpikir Kritis: Mendorong Introduksi dan Reformulasi Konsep dalam Psikologi Islam. Buletin Psikologi . 2018, Vol. 26, No. 2, 86-96

Baskoro Adi Prayitno dan Bowo Sugiharto Komparasi Model Pembelajaran Konstruktivis Metakognitif Dan Konstruktivis Novick Terhadap Berpikir Kritis Ditinjau Dari Kemampuan Akademik. INFERENSI, Jurnal Penelitian Sosial Keagamaan. Vol. 11, No.1, Juni 2017, 26

https:/www.kompasiana.com/baktigunawan/550d985b8133115d22b1 e4d8/penerapan-teori-belajar-vygotsky-dalam-interaksi-belajarmengajar

Brooks, J.G. \& Brooks, M. The case for constructivistic classrooms. Assosiation for supervision and curriculum development. Alexandria Virginia 1993. 
Cornelius-White, J. Learner-centered teacher-student relationships are effective: A meta-analysis. Review of Educational Research, 2007. 77(1), 113-143.

Chukwuyenum, A.N. Impact of Critical Thinking of Performance in Mathematics Among Senior Secondary School Student in Lagos State. Journal of Research \& Metode in Education, 2013. Vol. 3 Issue 5, pp. 18-25

Dahar, Ratna Wilis, Teori Belajar, Jakarta : Erlangga Press, 1989.

Dadang Supardan. Teori Dan Praktik Pendekatan Konstruktivisme dalam Pembelajaran Edunomic: Volume 4 No. 1 Tahun 2016.

Djamarah. Syaiful Bahri. Zain. Aswan. Strategi Belajar Mengajar. Jakarta: PT Rineka Cipta, 2007.

Faizal Amir Mohammad. Proses Berpikir Kritis Siswa Sekolah Dasar Dalam Memecahkan Masalah Berbentuk Soal Cerita Matematika Berdasarkan Gaya Belajar. Jurnal Math Educator Nusantara Volume 01 Nomor 02, Nopember 2015.

Jean Piaget, Teori Perkembangan Kognitif, Yogyakarta: Kanisius, 2001.

Lapono, N, dkk. Belajar Dan Pembelajaran SD. Jakarta: Dirjen Pendidikan Tinggi Depdiknas, 2008.

Mira Azizah1, Joko Sulianto, Nyai Cintang. Analisis Keterampilan Berpikir Kritis Siswa Sekolah Dasar Pada Pembelajaran Matematika Kurikulum 2013. Jurnal Penelitian Pendidikan Vol. 35 Nomor 1 Tahun 2018.

Paulina Pannen, Dina Mustafa, Mestika Sekarwinahyu. Konstruktivistik Dalam Pembelajaran. Jakarta: Proyek Pengembangan Universitas Terbuka Ditjen Dikti, 1991.

Sagala, Syaiful. Konsep dan Makna Pembelajaran Untuk Membantu Memecahkan Problematika Belajar dan Mengajar. Bandung: Alfabeta, 2007.

Sardiman A.M,. Interaksi dan Motivasi Belajar Mengajar. Jakarta : Raja Grafindo Persada, 2007.

Slavin, Robert E. Educational Psychology: Theory and Practice. $8^{\text {th }}$ Edition. Boston: Pearson Education, Inc. 2006.

Tim Dosen Fakultas Psikologi Unika Atma Jaya. Mempersiapkan Generasi Milenial Ala Psikolog: Kiat-kiat pendidikan anak bagi orang tua dan guru. Jakarta: PT Kompas Media Nusantara, 2018.

Thobroni. Belajar dan Pembelajaran. Yogyakarta: Ar-Ruzz Media, 2015. 